
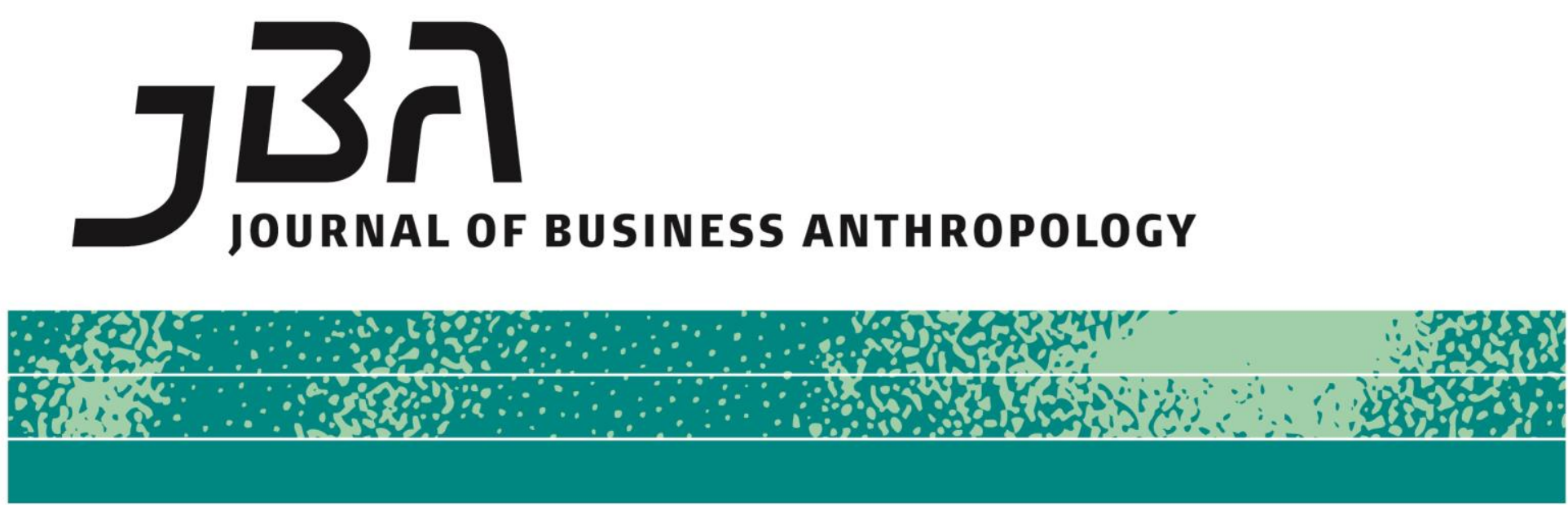

\title{
Too rare to be a token: An anthropologist in a management department
}

\author{
Alex Stewart
}

Howard Aldrich and I recently demonstrated the minuscule impact of anthropology in management publications, in contrast with the current flowering of business anthropology, and with the impacts of economics, psychology and sociology (Stewart \& Aldrich, forthcoming). We considered eight qualities of anthropology that could be obstacles to its impact: left wing ideology, exotic (read irrelevant) expertise, ethnography as the primary source of data, field access challenges, the lengthy duration

Page 1 of 19

JBA 3(2): 140-158 Fall 2014

(C) The Author(s) 2014 ISSN 2245-4217

www.cbs.dk/jba of ethnographic fieldwork, solo rather than multiple authorships, complex and contextualized findings, and greater emphasis on scholarly books than on journal articles. We concluded that none of these is an insurmountable obstacle to collaboration between management and anthropology researchers. Hopefully our outlook will be read as optimistic.

This essay has a hopeful cast as well, as I reflect on nearly 30 years as an anthropologist in management departments. Aldrich and I encouraged management scholars to engage with anthropologists, and suggested ways to do so. Here, my intended audience is anthropologists who might consider a career in a management department. ${ }^{1}$ I organize

\footnotetext{
${ }^{1}$ Considering the large numbers of business anthropologists in industry (Briody, 2014), we can hope that a few of these at least would (like Malcolm Chapman,
} 
my thoughts around the eight potential obstacles, from the perspective of the anthropologist rather than that of the management researcher. First, however, a sliver of my biography is needed as a context for my comments.

If I had tried to render my record opaque when I entered the market for business school faculty, I could scarcely have done a better job. In truth I could have left myself as even more of an outsider, because I took an M.B.A. at the all-but-dissertation stage for my doctorate, and I wrote my dissertation on an auto parts firm. However, my degrees (from York University in Toronto) reflected a zig zagging route: B.A., M.A. in Social Anthropology with East Asian languages; M.B.A. with a concentration in entrepreneurship; and Ph.D. in Political Science, with a major field of Canadian Politics and a minor field of Social Anthropology. My dissertation was also considered "qualitative"-a term heard more frequently in business schools than in anthropology departments. I then compounded these liabilities by publishing, as my first work on business, a scholarly book (Stewart, 1989). If I have survived such an inauspicious start, and also the later mistakes I confess to in this essay, surely other anthropologists can do better than I.

\section{Potential obstacle: Sympathy for the poor and left wing ideology.}

Not only was I educated first in the social sciences, but in Canada at the time of the Vietnam War, and in a university widely regarded (not completely correctly) as left wing. When I joined the M.B.A. program I was, therefore, not surprised to notice the different political orientation. A purpose of the program, it seemed, was to socialize management novitiates into positive views of markets and firms. Rather unexpected was my self-perception of a participant observer going native. The business school world began to feel more and more normal. One reason was realizing that business school professors are scholars first, and business professors second. I had expected they would focus their writings on matters of imminent practical utility, but found little difference from anthropologists in the value they placed on writings intended primarily, or only, for other academics.

Teaching in business schools is long on the merits of markets, but management journals sometimes publish critiques of corporations and of capitalism itself. Therefore, one way to reconcile the worldviews of anthropology and management was to become a "critical management scholar" (to use its current name; Stewart \& Aldrich, forthcoming). This was not an option for me, since I had slid too far into a managerial

Timothy Malefyt, and Brian Moeran, among others) consider a business school position. In Stewart and Aldrich, we cited many works by business anthropologists, such as Elizabeth Briody. With a different purpose in mind, I do not do so here. However, these writings and the developments they reflect encourage me to think that such readers might exist. 
mindset. Instead, my solution was to focus on entrepreneurship. I thought then, and I think now, that this is a way to support the creation of new wealth, broadly conceived, by people and communities in need. Moreover, thanks to my anthropological background, my conception of entrepreneurs was eclectic, including Swat Pathans, Melanesian Bigmen, and diverse micro-enterprising actors (Stewart, 1990; 1991).

\section{Potential obstacle: Ethnography as the data source}

Management departments do not understand ethnography. Method discussions in "qualitative" articles focus almost exclusively on data interpretation and analysis. ${ }^{2}$ As a signal to editors and reviewers that a study has methodological merit, an established canon of works will be cited. The customary references are on grounded theory (by Anselm Strauss with Juliet Corbin), and case study research (by Kathy Eisenhardt, and by Robert Yin). This is not a canon one learns in anthropology. That is unsurprising. None of these works pays attention to the quality of the fieldwork data. Judging by the "qualitative" studies that make it into management journals, and the manuscripts I am sent to review, weak fieldwork data cripple the majority. When I encounter a study based on high quality fieldwork, such as that by Salvato and Corbetta (2013), I am surprised.

My frustration with inapt routines for assessing ethnography led me, with John Van Maanen's encouragement, to write a short book for his "Qualitative Methods" series. The Ethnographer's Method ${ }^{3}$ (Stewart, 1998) remains-I think-the only comprehensive statement of method criteria for traditional ethnographic research. When I wrote it, I harbored no illusions that its prescriptions would be met with broad acceptance. Still, I had hoped the book would inspire a debate. This never materialized. The book received only one book review, in The Journal of Marketing Research. It was ignored by all of the journals in anthropology, sociology, ethnography or qualitative method.

Kindly excuse a few personal observations for a moment. I believe they refer to problems stemming in part from my affiliation with a business school, leading to the ecological fallacy of assuming that I would be imposing a conventionally quantitative and constraining methodological template. To the contrary, as Eric Arnould-the book's

\footnotetext{
2 The same focus and the same blind spot are found in the debates about grounded theory between adherents of Barney Glaser or Anselm Strauss (Glaser, 2008; Heath \& Cowley, 2004).

${ }^{3}$ The title is an anthropological allusion. Malinowski (1922/1961, p. 6; cited in Stewart, 1998, p. 65) asked, "What is then this ethnographer's magic?" and he answered, shortly thereafter, that it is "a patient and systematic application of... common sense and well known scientific principles... the principles of method." I do note that some "rhetorical fancy may well be at play in this passage, but not as much as it might at first appear."
} 
sole reviewer-realized: the book is an "unapologetic defense" of ethnography, and ethnography as understood by anthropologists (2000, p. 279). ${ }^{4}$ By contrast, an article by Lazaraton $(2003$, p. 6) concluded that my book "implies that evaluating various characteristics of methodological rigor is sufficient for ensuring 'quality' research." Here is what the book says on this matter: "Method is a necessary, but not a sufficient, contribution to the caliber of an ethnography" (Stewart, 1998, p. 65; see also p. 14).

Perhaps I have failed to this point to proffer hopeful signs for anthropological ethnographers in management. However, there are grounds for optimism. Unlike adherents to the canonical citations in management (Corbin and Strauss, and so on), anthropologists know that ethnography needs prolonged fieldwork, the search for disconfirming observations, good participative role relationships, and attentiveness to context. (These are the first four, and most important, requirements for good ethnography that I propose in The Ethnographer's Method.)

Anthropologists also bring a broad method toolkit to the field-they may, for example, be adept at social network analysis (Stewart \& Aldrich, forthcoming). Therefore, they could surprise the reviewers for management journals by submitting high quality work. My view is these journals reject "qualitative" studies more frequently than other works, but only because these submissions are weak. A study based on bad data cannot be remedied. If anthropologists do seek to publish in management journals, I suggest that they study the theories and norms in these outlets, team up with a scholar in management, or both.

\section{Potential obstacle: Access to business field sites.}

You would think that being in a business school would help to open up doors for field research on management. I suspect this is generally true. Nonetheless, their possible disadvantage has not stopped scholars in departments of anthropology or sociology from producing ethnographic studies of management (e.g. Kondo, 1990; Moeran, 1996; Miyazaki, 2013; Riles, 2011; Yanagisako, 2002). ${ }^{5}$ Moreover, not all business schools are well connected with business practitioners. Worse, the blindness of business schools to ethnographic requirements can be actively harmful. At a critical time in my career, a senior colleague explicitly blocked my access to the main organizations of any scale-other than the university-for many miles. On balance, being in an urban area with multiple field sites is probably more important than being in a business school. Being in a regionally well-regarded university is probably more important. Being in the right place at the right time-luck-is probably

\footnotetext{
${ }^{4}$ Arnould's review is explicitly favorable ("I like the book", p. 279), so I am biased in its favor. You can bear that in mind when I say that it has an accurate summary of the book.

${ }^{5}$ The reader might have noticed: these ethnographies are all set in Japan.
} 
even more important. Access for my 1989 book was opportunistic, as it was for many ethnographic studies of management, which were born from pre-existing roles such as employment, consulting, or family connections (e.g., Dalton, 1959; Gouldner, 1954; Lépinay, 2011; Pettigrew, 1985; Ram, 1994; Zaloom, 2006). As anthropologists well recognize, access tends to be a drawn-out process, fusing chance encounters between organizational gatekeepers and an agent-the would-be ethnographer-in search of possible field sites (as with Kunda, 2006).

\section{Potential obstacle: Fieldwork duration.}

Publication pressures in business schools direct their denizens to short duration projects with near-term potential for journal submissions. This behavior is driven in part by a failure to recognize the value of scholarly books, which can better accommodate reporting the results of longerterm fieldwork (discussed below). Professors in anthropology departments are more aware than their cross-campus colleagues of the need to accommodate such fieldwork. With decisions under their jurisdiction, such as the scheduling of teaching duties, they can offer more flexibility than other departments. Further, departmental members who bring in external grants may be able to head for far-off field sites.

These prospects vary by the national funding systems and by the institution's procedures, resources, and research focus. Unfortunately, anthropology departments cannot accommodate all their long-term field research needs with leaves or sabbaticals. They may be no more likely than other departments to manage the administrative and resource challenges. Even at Harvard, "by and large we [anthropologists] are treated like everyone else" (personal communication, John Comaroff, 1029-14). ${ }^{6}$ The only feasible options, even for those in anthropology departments, may be to work with locally accessible sites that can be studied intermittently, deploying some of the tools of "rapid appraisal" such as ethnographic interviews (Spradley, 1979; Stewart \& Aldrich, forthcoming; for the challenges of "episodic" fieldwork see Whyte, 2013).

\section{Potential obstacle: Solo authorship.}

Anthropologists are much more inclined than management scholars to produce solo authored writings (Stewart \& Aldrich, forthcoming). One reason for the pattern of multiple authors in business schools is that a common practice in evaluating faculty merit is to treat co-authorships equally with solo authorships. A modest exception is for cases of promotion and tenure, when authorship sequencing can be viewed as

\footnotetext{
${ }^{6}$ Thanks also for their assistance to Patrick Gray (University of Wisconsin Milwaukee), Danilyn Rutherford (UC-Santa Cruz), and Albert Schrauwers (York University).
} 
evidence of the candidate's own contributions and solo authorships can be evidence of the likelihood of continuing "productivity." However, when co-authorships are generally rewarded equally with solo authorships, solo authored works are disadvantaged. Worse yet, a pattern of solo authorships may be viewed unfavorably when departments hire a new faculty member. From the perspective of current members of the hiring department, their personal career interests are best served if the newcomer can help to augment their own publication records. For this reason, researchers with a track record of collaborative publications are attractive recruits.

I was a slow learner in this regard. For most of my career I was skeptical about the multi-authored model. I lacked ideas for collaborative projects, and my colleagues were unclear about how to work with me. My first collaborative effort was with Len Sayles, who had been one of the pioneering anthropologists in management, and recently retired from Columbia (Sayles \& Stewart, 1995). More recently I have learned to work with colleagues, both within and outside my department. With my departmental colleagues, one of my roles has been (ironically, it appears) the "numbers person" for bibliometric studies. Many anthropologists would be at home with the preparation this has required: becoming familiar with some of the literature on the sociology of knowledge and scientometrics, with such databases as the Web of Science, and with basic social network analysis. With my external colleagues, I found by chance a collaborative approach that has worked well and that I recommend: I brought in major scholars as second authors (Anne Miner of WisconsinMadison, Mike Hitt of Texas A\&M, and Howard Aldrich of UNC-Chapel Hill). Even if you should initiate the project and exert the majority of the energy, collaborators such as these more than earn their authorships with outstanding contributions to the publications.

\section{Potential obstacle: Complex and contextualized findings.}

"Anthropologists prefer depictions of idiosyncratic social processes to models of predicted or indeed predictable outcomes" (Stewart \& Aldrich, forthcoming). Management researchers instead prefer parsimonious modeling of generalizable relationships (Arnould \& Thompson, 2014). Of course there are limits to simplification about business. By the time I joined the business school, a "search for universals" in management had been displaced in favor of "contingency theory" (Thompson, 1967, p. vii). This school of thought avoided universal prescriptions, but it still showed a bias for simplifications of its own. At this time-the 1980s-I worried that management thought was being reduced to the once-ubiquitous two-

\footnotetext{
${ }^{7}$ Anthropology departments are probably not immune from this tendentious term. Much as I value scholarship, I doubt that many of a university's stakeholders regard our publications as the only, or even the most important, of our contributions.
} 
by-two matrixes of the sort found in Hofer (1975), in which questions of business strategy are explained by such matrixes as: "degree of product differentiation" ("high" and "low"); "Nature of buyer needs" ("primarily economic" and "primarily noneconomic") (p. 802; also Thompson, 1967, pp. 72, 86, 134 for other examples).

Fortunately, management scholars would come to recognize "problems with contingency theory", as it "underrepresents the complexity of relations between [such variables as] technological uncertainty, structure, and organizational effectiveness" (Schoonhoven, 1981, title and p. 369). Even popular management books may resist excessive simplifications. Katzenbach and Smith's The Wisdom of Teams, for example, shows the marks of Smith's anthropological background (e.g. the call for managers to "find [the real teams], watch them in action, check their results [and] talk to them", 1993, p 263). We might also recall the "top dog... [among] management gurus... Peter Drucker... [who] is one of the few thinkers from any discipline who can claim to have changed the world" (Micklethwait \& Wooldridge, 1996, p. 63). Drucker's (1973) classic work Management: Tasks, Responsibilities, Practices (given to me by my father, a manager, who had read the book), runs 839 pages with not a single two-by-two or figure of any sort.

Drucker's success suggests an opportunity for anthropologists. Many fields in management, such as international and cross-cultural studies, lend themselves poorly to broad-brush modeling or heuristics. Such simplifications have not been lacking-sadly, some have been highly influential, such as the "national cultures" approach popularized by Hofstede (Brøgger, 2013; McSweeney, 2002). By anthropological standards, business school research on global cultures or countries has been dilettantish. Management has nothing along the lines of Bashkow (2004), Burton, Moore, Whiting and Romney (1996), or Hays (1993) (as examples). Fortunately, the superficiality of the literature in a niche can open up possibilities. More nuanced and scholarly work on this and other topics could make a well-recognized contribution, provided that the managerial relevance of the subtleties is clear enough. Relevance will trump elegance for many readers.

\section{Potential obstacle: More books, fewer articles.}

Books can be "meritorious." Most management departments do not encourage, and may actively discourage, book publication (Cotton \& Stewart, 2013). Yet all is not lost for the wayward anthropologist hoping for merit rewards or for tenure in management, based partly on book publications. If the tenure case reaches the university level, the committee will likely have professors from the social sciences and humanities who value scholarly books. The case may very well reach that level if the departmental and college committee recognize that, having hired an anthropologist, they should consider the way anthropologists work. 
Everything depends on the receptiveness of people in the particular institution. In tenure decisions "excellence becomes whatever a majority of voting tenured faculty members in a particular department at a particular time say it is" (Whicker, Kronenfeld, \& Strickland, 1993, p. 26).

Moreover, authors of scholarly books have a prospect of gratifications, irrespective of institutional rewards. Some of management's most highly cited works are books: Porter (1980, with 6,349 Web of Science citations as of 10-24-2014), Pfeffer and Salancik (1978, with 5,544), Thompson (1967, with 5,437), and March and Simon (1958, with 5,390 citations) (see generally Bedeian \& Wren, 2002). ${ }^{8}$ These hugely cited books are conceptual syntheses, not field studies. The most highly cited books about management that are based on intensive field studies are Burns and Stalker (1961, with 2,588), Kunda (2006, with 697), Bower (1986, with 634), and Pettigrew (1985, with 577). (Kunda is rather peripatetic, serving at times as a "labor studies" professor.)

It is hard to argue that the time spent producing a book will be better rewarded than the same time spent writing articles. Clearly, the best approach is to publish some articles and then an affiliated book-common practice in anthropology (e.g. articles associated with Kondo, 1990; Moeran, 1996; Riles, 2011). However, this was not my own practice. Still, my books have been helpful and I do not regret doing them. They were among the reasons I made tenure at Texas Tech and Full Professor at Marquette. ${ }^{9}$ They gained me the assistance-testimonials, coauthorships, and reference letters-of prominent scholars. Examples include the efforts of Howard Stevenson (Sarofim Rock Chair at Harvard Business School) and Anne Huff (then of the University of Illinois) to persuade Sage to publish Team Entrepreneurship. That book then led to my first position in a doctoral department, after its head, Carlton Whitehead, read the book and liked it. It led to other connections, with John Van Maanen of MIT and Howard Aldrich of Cornell and UNC-Chapel Hill. If you send a scholar a book in the post you will get more attention than if you send a paper by email.

\section{Potential obstacle: Exotic expertise.}

Though I did not foresee it when I switched to Political Science for my

\footnotetext{
8 These books are more highly cited than the most highly cited management articles I can find, using the Web of Science's "TS = topic" searches and sorting by the most cited first. The most cited management article is in the topic field of "Strategic Management": Teece, Pisano and Shuen (1997) with 4,491 citations. The next highest is also in the same field, with a similar topic: Eisenhardt and Martin (2000) has 2,183 citations. The next is in "Human Resource Management": Huselid (1995) has 1,751 (all citations as of 10-25-2014).

${ }^{9}$ At Texas Tech my tenure was supported by Shelby Hunt. I mention this because Shelby, a prominent Marketing scholar, is sometimes thought to be opposed to ethnography. He is not; he opposes work that is hostile to science, to markets, or both.
} 
Ph.D., my first two degrees in social anthropology would become the basis for my scholarship, just as my M.B.A. would become the basis for my teaching. My studies in those first two degrees could certainly be labeled "exotic." In those days (and currently) my regional interest was East Asia, and I completed 12 credit hours in Classical (BCE) Chinese as well as modern Chinese and Japanese. Within the anthropology department, the most prominent professor, P. H. Gulliver, had been an Africanist, as had several of his colleagues. Much of a semester in one course consisted of the intensive study of Evans-Prichard's The Nuer, published in 1940: we lived in an ethnographic present. This was not all bad-the assumption was that we learn enduring social principles from the study of any culture at any time. ${ }^{10}$ Although I accepted this assumption, my interests at the time were turning towards the domestic. I wrote my masters' thesis on French-English relations in the Conservative Party of Canada. This was the start of a gradual transition to the study of contemporary organizations.

To label the shift a "gradual transition" is to gloss over how lurching and murky was the path. At many twists and turns I needed a mentor but lacked one, at least for the challenge at hand. For example, how do you prepare a job talk for a business school? How do you present in a management conference? What business school specialty should I choose? Any anthropologist entering a business school must answer this question. On that question I received kindly advice from my professors, but I was not always amenable to their suggestions. I was not sufficiently interested in business-government relations; international business seemed too economics oriented; consumer behavior was too micro for my tastes. In retrospect, I might have thrived in marketing. Although it was not yet apparent, anthropologists would turn out to make important impacts in marketing, and especially in consumer behavior (compare Arnould \& Thompson, 2014). I made my choice-perhaps a romantic one-in favor of entrepreneurship, and it was housed within management. Housed, that is, in the few places it existed; in the early 1980s it was still a marginal field with few entry-level jobs.

Challenges of writing in business schools. Having chosen a specialty, another challenge will loom for the business school anthropologist: writing for business school journals. How do you learn to write in accordance with their customs? To what extent do you write as an anthropologist? What topics do you write about? On the first question, everyone can learn, painfully, by reading reviews and rejection letters. As I have suggested, I would have learned faster if I had been a co-author at this time. On the second and third questions, I received signals, such as invitations to speak on panels, that there was a niche for translations and

10 I was delighted to be able to buy or trade for "E.P.'s" Witchcraft, Oracles and Magic among the Azande (Evans-Pritchard, 1937) and The Sanusi of Cyrenaica (Evans-Pritchard, 1949), both of which adorn my shelves. (Their titles are hard to match in the business literature.) 
syntheses, for management scholars, of anthropological knowledge.

Because there are still so few anthropologists in management, I suspect there remain many such opportunities. More recently, as an example, I have begun to draw out the implications of kinship studies for so-called "family business." 11

Although I made my living at times with these translations, I found three problems that you should bear in mind if you also wish to do something similar. First, being in a business school and not an anthropology department, writing for journals that are ill prepared to review anthropological manuscripts, means that you need to be your own most scrupulous reviewer. For me, the thoughts that an anthropologist might chance to read my writings, and that my management colleagues have nobody else to count on, has inspired a sedulous, perhaps overly pedantic, style.

Second, my introductory papers (introducing the anthropology of entrepreneurship in Stewart, 1991, and the anthropology of "family business" in Stewart, 2003) have been better received, certainly more cited, than my more adventurous work on similar topics (Stewart, 1990; 2010). At times this made me wonder if I would have been better off in an anthropology department. Then I would reassure myself that at least I am free from the fashions and contestations in those departments. However-and this is the third problem-we have scholarly fashions of our own in business schools. At a crucial phase in my career, as an assistant professor at Texas Tech, I felt a pressure to become a more conventional business school researcher. Perhaps this pressure existed only in my imagination. Regardless, I suspect that many anthropologists would have similar experiences. Hopefully they would resist this pressure better than I did, as I believe I would have been better to stick with my core, anthropological, strengths.

Challenges of teaching in business schools. Unlike the social sciences, in which undergraduates read scholarly writings, business education largely reserves such exposure to the doctoral level. Therefore, a challenge facing early-stage business school instructors, including many of those with training in business schools, is learning to teach in a practice-focused classroom. In certain fields, such as economics, synthesizing and explicating current theory can be a feasible approach. In well-established management fields, such as organizational behavior and strategic management, professors differ on their assessment of the managerial relevance of these literatures (Starkey \& Madan, 2001). For some, a heavy dose of research findings should be included in the

11 Much of my current reputation rests on my work in this area, but I do not believe the term is scientifically helpful. It is a folk term treated as a taxonomic term. If-as so often claimed-the great majority of businesses worldwide are "family businesses" it is hard to argue that this classification tells us much of anything. Yet I do believe that the interfaces of kinship and business are complex, crucial, and worthy of scientific (i.e. ethnographic) study (Stewart, 2014). 
classroom mix. Some of my colleagues may think the same of entrepreneurship, but I am skeptical. If you believe, as I do, that your teaching role (doctoral teaching excepted) is to coach your students towards successful venture starts, you will be hard pressed to find your teaching materials in academic research. On balance, I find this to be a license for exploration and learning on my part as well as my students.

The cost of freedom from textbooks or articles is the need for some general business knowhow. How much is needed depends on your subfield of management. Relatively more such knowledge is needed in entrepreneurship and strategic management. More is needed in international business than in international management. (The former includes topics such as hedging exchange rates; the latter focuses on "softer" topics like organizational and so-called "national" culture.) Relatively less is needed in human resource management, business ethics, and (probably) organizational behavior. Specialized scholarly expertise in these fields will need to be transmitted. However, as in any field of learning, little is really transmitted if it is not actively learned in terms and in contexts that students already understand to some degree (Bain, 2004).

The good news about the need for active and student-centered learning is that we, as instructors, do not need to have-and could not have-all the knowledge necessary in our subjects. We do need to learn how to teach accordingly, to draw on what our students care about and know, and this is yet another lesson that it took me some time to learn. But as we shift towards such a teaching approach, away from the professing expert approach, we also accumulate knowledge. In my field of entrepreneurship instruction, there are many ways to accumulate general business and venturing knowhow that follow, as by-products, from doing our jobs. Here are some of the ways that we learn, based on my experience:

- Completing an MBA. This was my path, but these days you would also consider MOOCs. They lack much credentialing panache but they let you fill in the idiosyncratic gaps in your knowledge.

- Working in a business. In my case, right after my M.B.A., I reported to the General Manager of a highly autonomous division of Magna International, leading to my Ph.D. dissertation and my first book, Team Entrepreneurship.

- Teaching a practice-focused approach to entrepreneurship. Like other fields, you can learn by teaching, both in the preparation and in the interaction with students.

- Developing the infrastructure for an entrepreneurship program. For example, I helped to launch an angel investor network, and a small incubator with links to mentors and community resources, in collaboration with a clinical professor. 
- Doing fieldwork in entrepreneurial ventures, possibly in collaboration with doctoral students.

- Advising dozens or hundreds of semester-long consulting projects for business owners.

- Starting and running a teaching program for business owners. You probably should wait a while before trying this.

- Starting a side business. If you have a day job the challenge is to take this seriously enough, as you do not need financial success.

In my case I found another opportunity: marrying or otherwise cohabiting with an entrepreneur. The opportunity might have you passed by, but if so you could encourage your partner to become an entrepreneur! I was lucky on this score.

Anthropology is well suited to practical entrepreneurship education. Anthropologists should be predisposed to current approaches to teaching entrepreneurship that are found within universities and institutions such as venture accelerators. Current thinking emphasizes the practice-based discovery of what particular customers truly want and will pay for (Neck, Greene, \& Brush, 2014). Therefore, entrepreneurship education spends less time than in the past on business plans. Instead, it encourages an incremental learning process, as the would-be startup seeks market validation of its viability (Rencher, 2014). The scholarly rationale for this approach is that "entrepreneurs who engage in experimentation and who interact early and often with customers will be able to overcome many of the hurdles associated with starting a venture" (Fisher, 2012, p. 1046). In popular business writings this approach is branded as "lean": lean startups, lean customer development and so on (Alvarez, 2014; Ries, 2011).

Figure 1. Business Model Canvas, Adapted from Osterwalder \& Pigneur (2010)

\begin{tabular}{|l|l|l|l|l|}
\hline \multirow{2}{*}{$\begin{array}{l}\text { Key } \\
\text { Partnerships }\end{array}$} & $\begin{array}{l}\text { Key } \\
\text { Activities }\end{array}$ & $\begin{array}{l}\text { Value } \\
\text { Propositions }\end{array}$ & $\begin{array}{l}\text { Customer } \\
\text { Relationships }\end{array}$ & $\begin{array}{l}\text { Customer } \\
\text { Segments }\end{array}$ \\
\cline { 2 - 2 } & $\begin{array}{l}\text { Key } \\
\text { Resources }\end{array}$ & & Channels & \\
$\begin{array}{l}\text { Cost } \\
\text { Structure }\end{array}$ & & \multicolumn{2}{|l}{} \\
\hline $\begin{array}{l}\text { Startup } \\
\text { Capital }\end{array}$ & & \multicolumn{2}{|l}{} \\
\hline
\end{tabular}


A widely adopted, focal heuristic in this approach is the "business model canvas" (Osterwalder \& Pigneur, 2010). ${ }^{12}$ The version that I teach with is shown in Figure 1. The bottom two "blocks", for Startup Capital and Competitive Environment, are my additions based on teaching experience. I also have my students complete either an "art" project that conveys the hoped-for experiences of the customers ${ }^{13}$, or (for those reluctant to use other media), the "Empathy Map" of the customer's subjective states (e.g. "what does she think and feel?...What does she hear?..." Osterwalder \& Pigneur, 2010, pp. 130-131). I add this assignment because a primary foundation for a successful business model is the match between the "Value Propositions" ("the bundle of products and services that create value for a specific Customer Segment" and (by definition) the "Customer Segments" (Osterwalder \& Pigneur, 2010, p 22). The challenge this project creates is showing that this match is not a figment of the would-be entrepreneur's imagination. An outstanding project will reflect an understanding of the hoped-for customer experience and its meaning(s) in terms of the customer's own "heartmind" (心xin, to adopt the classical Chinese conception).

Before anthropologists could coach their students with this approach, most would need prior preparation for some of the blocks. Nonetheless, they bring a great deal to the table from the start. Their fit applies most obviously to the five blocks that are, in my view, the crucial foundations of the model. The fulcrum of the model is the fit between the "Value Propositions" and the "Customer Segments." These marketing issues are the sweet spot for business anthropologists (Sunderland \& Denny, 2007). Among the reasons for their competency is their approach to learning what consumers in their natural settings actually do, not just what they say.

"Key Activities" is a stumbling block for many students, who underestimate what tasks a firm must carry out in order to provide the Value Propositions. This is a stumbling block as well for disciplines that treat the firm in abstract terms. Anthropologists are inclined to envision the full human scope of the organization. Once the Key Activities are recognized, the Key Resources needed to carry them out must be identified. Many of these are intangible, such as forms of intellectual property. Here again, anthropologists might not know the terminology current in business, but they are well prepared for topics of this sort. Moreover, they are accustomed to learning local jargon. Lastly, in any venture there will be gaps between its legacy and readily found resources

\footnotetext{
12 Osterwalder, Pignuer, Bernarda, and Smith (2014, p. 61) have added a "Value Proposition Canvas."

13 "Art" projects have included many media and media combinations. Marquette is certainly not an art school, but some of these projects have been outstanding, including two wonderful videos of dance performances.
} 
and the needed Key Resources. These gaps are filled with Key

Partnerships. Anthropologists are attuned to social networks, and alert to under-recognized social actors. In fact, this alertness to what others neglect is an important quality of entrepreneurs, and hence also of their teachers.

\section{Final thoughts: The management anthropologist role}

I hope I have made clear that there is no such role. All roles are to some degree constructed, not givens, yet the metaphor itself implies there are scripts to be enacted (Zaleznik, 1965). My colleagues, my editors, my overseers, and I had none of these. Nor would you, the anthropologist who thinks of joining a management department. Organizations develop established routines for dealing with under-represented members, but management departments (and probably marketing departments as well: Arnould \& Thompson, 2014), do not have routines for dealing with anthropologists. Like me, you would not even be a token. You could, of course, learn from the mistakes I have made. However, much will depend on the particular department that would hire you.

Lacking recognized scripts, anthropologists and their institutional colleagues are challenged to improvise. They are challenged to make "mutual accommodations," to use Burns and Stalker's (1961) term for coordination in "organic" organizations. My employers and I have done so, or I would not have lasted in my profession. Sadly, universities worldwide are increasingly caught up in movements towards bureaucratic performance appraisal. They are becoming, in Burns and Stalker's terms, more and more "mechanistic." This does not mean, however, that their systems of formal assessment and accountability are, or can be, rigidly established (at least, not in North America; I am less hopeful about the UK). A university is a complex organization, but an odd one: a "loosely coupled" "organized anarchy," in Cohen, March and Olsen's (1972) terms. Anthropologists, of all people, ought to be able to scope out its folkways and to help massage its systems to render them more inclusive and tailored to the particular institution (Cotton \& Stewart, 2013). This ecumenical project would be bolstered if more anthropologists would join me in making their living in a business school. That is my hope in writing this essay.

\section{References}

Alvarez, Cindy. 2014. Lean customer development: Building products your customers will buy. Sebastopol, CA: O’Reilly Media.

Arnould, Eric J. 2000. Review of A. Stewart 1998, The ethnographer's method. Journal of Marketing Research, 37, 279-280. 
Arnould, Eric J., and Thompson, Craig J. 2014. Living in business schools, writing consumer culture. In Rita Denny and Patricia Sunderland (Eds.), Handbook of anthropology in business, 116-134. Walnut Creek, CA: Left Coast Press.

Bain, Ken. 2004. What the best college teachers do. Cambridge, MA: Harvard University Press.

Bashkow, Ira. 2004. A neo-Boasian conception of cultural boundaries. American Anthropologist, 106, 443-458.

Bedeian, Arthur G., and Wren, Daniel A. 2001. Most influential management books of the $20^{\text {th }}$ Century. Organizational Dynamics, 293, 221-225.

Bower, Joseph L. 1986. Managing the resource allocation process: A study of corporate planning and investment. Cambridge, MA: Harvard Business School Press.

Briody, Elizabeth K. 2014. Building momentum for the JBA. Journal of Business Anthropology, 3(1), 5-10.

Brøgger, Benedicte. 2013. The rise and demise of a supply chain. Journal of Business Anthropology, 2(2), 232-253.

Burns, Tom, and Stalker, G. M. 1961. The management of innovation. London: Tavistock.

Burton, Michael L., Moore, Carmella C., Whiting, John W. M., and Romney, A. Kimball, with comments by Aberle, David F., Barcelo, Juan A., Dow, Malcolm M., Guyer, Jane I., Kronenfeld, David B., Levy, Jerrold E., and Linnekin, Jocelyn. 1996. Regions based on social structure. Current Anthropology, 37(1), 87-123.

Cohen, Michael D., March, James G., and Olsen, Johan P. 1972. A garbage can model of organizational choice. Administrative Science Quarterly, 17, $1-25$.

Cotton, John L., and Stewart, Alex. 2013. Evaluate your business school's writings as if your strategy matters. Business Horizons, 56, 323-331.

Dalton, Melville. 1959. Men who manage: Fusions of feeling and theory in administration. New York: Wiley.

Drucker, Peter F. 1973. Management: Tasks, responsibilities, practices. New York: Harper and Row.

Eisenhardt, Kathleen M., and Martin, Jeffrey A. 2000. Dynamic capabilities: What are they? Strategic Management Journal, 21, 1105-1121.

Evans-Pritchard, E. E. 1937. Witchcraft, oracles and magic among the Azande. London: Oxford University Press.

Evans-Pritchard, E. E. 1940. The Nuer: A description of the modes of livelihood and political institutions of a Nilotic people. London: Oxford University Press. 
Evans-Pritchard, E. E. 1949. The Sanusi of Cyrenaica. London: Oxford University Press.

Fisher, Greg. 2012. Effectuation, causation, and bricolage: A behavioral comparison of emerging theories in entrepreneurship research.

Entrepreneurship Theory and Practice, 365, 1019-1051.

Gouldner, Alvin W. 1954. Patterns of industrial bureaucracy: A case study of modern factory administration. New York: Free Press.

Glaser, Barney G. 2008. Conceptualization: On theory and theorizing using grounded theory. International Journal of Qualitative Methods, 12, 23-38.

Hays, Terence E., with comments by Brown, Paula, Harrison, Simon, Hauser-Schäublin, Brigitta, Hayano, David M., Hirsch, Eric, Jorgenson, Dan, Knauft, Bruce M., Lederman, Rena, Lipuma, Edward, Ogan, Eugene, Strathern, Andrew, Weiner, James F., and Westermark, George D. 1993. The New Guinea Highlands: Region, Culture Area, or Fuzzy Set? Current Anthropology, 34(2),141-164.

Heath, Helen, and Cowley, Sarah. 2004. Developing a grounded theory approach: A comparison of Glaser and Strauss. International Journal of Nursing Studies, 41, 141-150.

Hofer, Charles W. 1975. Toward a contingency theory of business strategy. Academy of Management Journal, 18, 784-810.

Huselid, Mark A. 1995. The impact of human resource management practices on turnover, productivity, and corporate financial performance. Academy of Management Journal, 38, 635-672.

Katzenbach, Jon R., and Smith, Douglas K. 1993. The wisdom of teams: Creating the high-performance organization. Cambridge, MA: Harvard Business School Press.

Kondo, Dorrine K. 1990. Crafting selves: Power, gender, and discourses of identity in a Japanese workplace. Chicago: University of Chicago Press.

Kunda, Gideon. 2006. Engineering culture: Control and commitment in a high-tech corporation, Rev. Ed. Philadelphia, PA: Temple University Press. (Original work published 1992.)

Lazaraton, Anne. 2003. Evaluative criteria for qualitative research in applied linguistics: Whose criteria and whose research? The Modern Language Journal, 87(1), 1-12.

Lépinay, Vincent Antonin. 2011. Codes of finance: Engineering derivatives in a global bank. Princeton, NJ: Princeton University Press.

Malinowski, Bronislaw. 1961. Argonauts of the western Pacific. New York: Dutton. (Original work published 1922.)

March, James G., and Simon, Herbert A. 1958. Organizations. New York: Wiley.

McSweeney, Brendan. 2002. Hofstede's model of national cultural 
differences and their consequences: A triumph of faith-a failure of analysis. Human Relations, 55, 89-118.

Micklethwait, John, and Wooldridge, Adrian. 1996. The witch doctors: Making sense of the management gurus. New York: Times Books.

Moeran, Brian. 1996. A Japanese advertising agency: An anthropology of media and markets. Honolulu: University of Hawai'i Press.

Mullins, John. 2014. The customer-funded business. New York: Wiley.

Miyazaki, Hirokazu. 2013. Arbitraging Japan: Dreams of capitalism and the end of finance. Berkeley: University of California Press.

Neck, Heidi M., Greene, Patricia G., and Brush, Candida G. 2014. Teaching entrepreneurship: A practice-based approach. Northampton, MA: Edward Elgar.

Osterwalder, Alexander, and Pigneur, Yves. (2010). Business model generation: A handbook for visionaries, game changers, and challengers. New York: Wiley.

Osterwalder, Alexander, Pigneur, Yves, Bernarda, Greg, and Smith, Alan. (2014). Value proposition design. New York: Wiley.

Pettigrew, Andrew M. 1985. The awakening giant: Continuity and change in Imperial Chemical Industries. Oxford, UK: Blackwell.

Pfeffer, Jeffrey, and Salancik, Gerald R. 1978. The external control of organizations: A resource dependence perspective. New York: Harper and Row.

Porter, Michael E. 1980. Competitive strategy: Techniques for analyzing industries and competitors. New York: Free Press.

Ram, Monder. 1994. Managing to survive: Working lives in small firms. Oxford, UK: Blackwell.

Rencher, Marlo. 2014. Value and the valley of death: Opportunities for anthropologists to create and demonstrate value in entrepreneurial contexts. Practicing Anthropology, 362, 52-56.

Riles, Annelise. 2011. Collateral knowledge: Legal reasoning in the global financial markets. Chicago: University of Chicago Press.

Ries, Eric. 2011. The lean startup: How today's entrepreneurs use continuous innovation to create radically successful businesses. New York: Random House.

Salvato, Carlo, and Corbetta, Guido. 2013. Transitional leadership as a facilitator of successors' leadership construction. Family Business Review, $26,235-255$.

Sayles, Leonard R., and Stewart, Alex. 1995. Belated recognition for work flow entrepreneurs: A case of selective perception and amnesia in management thought. Entrepreneurship Theory and Practice, 193, 7-23. 
Schoonhoven, Claudia Bird. 1981. Problems with contingency theory: testing assumptions hidden within the language of contingency "theory". Administrative science quarterly, 349-377.

Spradley, James P. 1979. The ethnographic interview. New York: Holt, Rinehart and Winston.

Starkey, Ken, and Madan, Paula. 2001. Bridging the relevance gap: Aligning stakeholders in the future of management research. British Journal of Management, 12(s1), S3-S26.

Stewart, Alex. 1989. Team entrepreneurship. Newbury Park, CA: Sage Publications.

Stewart, Alex. 1990. The bigman metaphor for entrepreneurship: A "library tale" with morals on alternatives for further research. Organization Science, 12, 143-159.

Stewart. Alex. 1991. A prospectus on the anthropology of entrepreneurship. Entrepreneurship Theory and Practice, 162, 71-91.

Stewart, Alex. 1998. The ethnographer's method. Newbury Park, CA: Sage Publications.

Stewart, Alex. 2003. Help one another, use one another: Toward an anthropology of family business. Entrepreneurship Theory and Practice, 27, Summer: 383-396.

Stewart, Alex. 2010. Sources of entrepreneurial discretion in kinship systems. In Stewart, Alex, Lumpkin, G. Thomas, and Katz, Jerald A. Eds., Entrepreneurship and family business, Vol. 12 of Advances in Entrepreneurship, Firm Emergence and Growth. Bingley, UK: Emerald Group, 291-313

Stewart, Alex. 2014. The anthropology of family business: An imagined ideal. In Leif Melin, Mattias Nordqvist, and Pramodita. Sharma Eds., SAGE Handbook of Family Business, Newbury Park, CA: Sage, 66-82.

Stewart, Alex, and Aldrich, Howard. forthcoming. Collaboration between management and anthropology researchers: Obstacles and opportunities. Academy of Management Perspectives.

Sunderland, Patricia L., and Denny, Rita M. 2007. Doing anthropology in consumer research. Walnut Creek, CA: Left Coast Press.

Teece, David J., Pisano, Gary, and Shuen, Amy. 1997. Dynamic capabilities and strategic management. Strategic Management Journal, 18, 509-533.

Thompson, James D. 1967. Organizations in action. New York: McGrawHill.

Whicker, Marcia Lyn, Kronenfeld, Jennie Jacobs, and Strickland, Ruth Ann. 1993. Getting tenure. Thousand Oaks, CA: Sage Publications.

Whyte, Michael. 2013. Episodic fieldwork, updating, and sociability. Social Analysis, 57, 110-121. 
Yanagisako, Sylvia Junko. 2002. Producing culture and capital: Family firms in Italy. Princeton, NJ: Princeton University Press.

Zaleznik, Abraham. 1965. Interpersonal relations in organizations. In James G. March Ed., Handbook of organizations. Chicago: Rand McNally and Company, 574-613.

Zaloom, Caitlin. 2006. Out of the pits: Traders and technology from Chicago to London. Chicago: University of Chicago Press.

Alex Stewart has made his academic career in business schools: Brock University, Texas Tech University, and Marquette University. His education in social anthropology (York University, Toronto) has been the foundation of his scholarship dating from his dissertation (1987) to the present. Recent and continuing interests include the relationships between kinship and entrepreneurial activity. An interest in China, begun as an undergraduate, has recently been rekindled, and he hopes to work on kinship, entrepreneurship, and environmental (non)sustainability in the Chinese context. He is Professor of Management and Coleman Foundation Chair in Entrepreneurship at Marquette University in Milwaukee, Wisconsin. He can be reached at alex.stewart@marquette.edu 